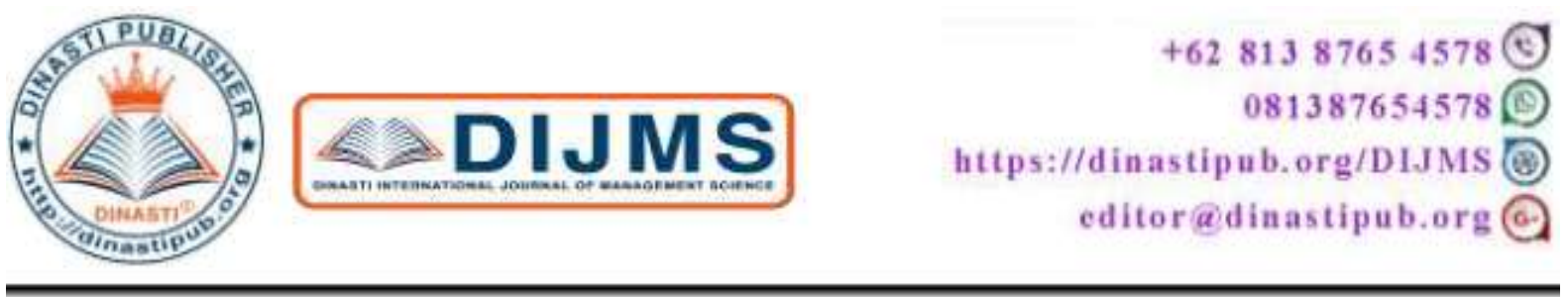

\title{
THE EFFECT OF COMPENSATION, COMPETENCE, AND LEADERSHIP ON MINISTRY OF INDUSTRION'S PUBLIC EMPLOYEES PERFORMANCE
}

\section{Jailani ${ }^{1)}$, Lenny C. Nawangsari ${ }^{2}$}

${ }^{1,2)}$ Fakultas Magister Manajemen, Universitas Mercu Buana, Jakarta, Indonesia

\begin{tabular}{|l|l|}
\hline ARTICLE INFORMATION & $\begin{array}{l}\text { Abstract: The purpose of this research is to } \\
\text { investigate the effect of compensation, competence } \\
\text { Received: 25 February 2020 } \\
\text { and leadership on employee performance. This } \\
\text { Issued: 22 March 2020 } \\
\text { research was conducted at the Ministry of Industry, the } \\
\text { responses used were 81 employees in the Ministry of } \\
\text { Industry. The data processed by using Statistical } \\
\text { Package for the Social Sciences (SPSS) Version 24. } \\
\text { The resultsof this research showing that compensation } \\
\text { Jailani } \\
\text { E-mail: } \\
\text { jaialan93@ gmail.com effect and no significant effect on performance, } \\
\text { lenny.christina@mercubuana.ac.id } \\
\text { on other hand competence has significant effect on } \\
\text { performance and also leadership has significant effect } \\
\text { on performance. } \\
\text { Keywords: Compensation, Competence, Leadership, } \\
\text { Performance. }\end{array}$ \\
&
\end{tabular}

\section{INTRODUCTION}

On today's competitive world, where the companies always competingto getthe best talent, and developing the good quality of HR brand is very important. On HR perspective, brand creation refers to the image or culture of the company itself.

As a manager for sure they want an employee with high-performance. But in reality between desires and facts can get negative experience deviations. There must be a problem. In fact, let's say the employees have an average of five years work experience with an average diploma level of education. It is suspected that there are factors that effected it, namely unclear roles, low competence, diversity of value systems owned by employees, different preferences, and lack of appreciation

Role clarity itself is not enough to boost employee performance. There are other factors that affect employee performance, such as the competency they have. Competencies are divided into two that is "hard" competencies like knowledge and skills, and "soft" competencies like attitude, work ethic, motivation, initiative, creativity, and empathy. The last type of competency is soft skills. 
Competencies can also be grouped into visible and hidden ones. The visible competencies known as knowledge that is characterized by ownership of the certification, and expertise that is reflected by their position and daily job status. While the hidden competencies is values, such as the ability of employees to make balances between work and family interests; self concept or self confidence; and personality such as honest, motivated and wise. The higher standard of the employeecompetency the higher performance that it produces.

If the clarity of roles and competencies has been fulfilled, so the employees will be able to give a better performance if supported by a comfortable work environment. The work environment here is seen from the physical and non-physical environment. The physical environment is like work facilities including work equipment, rooms, chairs and tables, electricity, air conditioning, low noise, and safety devices. While the non-physical environment includes participatory managerial leadership style, compensation, the quality of vertical and horizontal relationships such as togetherness and the social environment. The more comfortable of work environment the higher performance of the employee.

Basically every human, no matter how small the requires need an appreciation from others. For example, it needs to be greeted, loved, helped and prayed for. So they need a recognition from the others for the existence of the individual concerned. In the field of work, rewards needed by employees are not only for financial compensation but also non-financial. Financial compensation are salaries, wages, incentives and bonuses. While non-financial compensation are career path, achievement awards and acknowledgments. Ignoring appreciation for employees is ignoring basic human needs. Though appreciation is a vital element to build a motivation and satisfaction for employees to improve their performances.

Factors that related to influencing performances of the employeehas been widely studied. But of course not all factors are related or has significant effect performance. It is closely related to the type of organization in profit or non-profit; whether BUMN or non-BUMN. Then employee performance is also closely related to organizational competency factors, the scale or size of the organization's business, the characteristics of the company as a learning organization, employee characteristics, type of work, organizational culture, and managerial leadership style in the organization. Thus the factors that influence employee performance tend to be diverse and very situational according to the conditions of the company or their respective organizations. The same phenomenon can occur in every company or organization, including the Ministry of Industry.

According to the mandate of Law No. 3 of 2014 concerning Industry, the Directorate General of Resilience and Development of International Industrial Access has the task of increasing the development of Industrial resources through opening industry access either by carrying out capacity building within the framework of $G$ to $G$ Cooperation or others and increasing industrial empowerment through cooperation international, opening access to foreign investment through licensing, industrial investment and facilitation and taking security and industrial rescue measures. The number of employees that are still active on ministry of Industrion's public staff is 101 people (as of 2019) Tabel 1 Work Assasment Periode 2017 - 2019.

Table 1. Work assessment Periode 2017 - 2019

\begin{tabular}{|c|c|c|c|}
\hline \multirow{2}{*}{ Months/Years } & \multicolumn{3}{|c|}{ Performance Rating } \\
\cline { 2 - 4 } & $\mathbf{2 0 1 7}$ & $\mathbf{2 0 1 8}$ & $\mathbf{2 0 1 9}$ \\
\hline Januari & 90.54 & 96.82 & 95.16 \\
\hline Februari & 95.60 & 94.95 & 95.23 \\
\hline Maret & 95.58 & 93.63 & 94.56 \\
\hline April & 95.61 & 96.87 & 96.76 \\
\hline
\end{tabular}




\begin{tabular}{|c|l|l|l|}
\hline Mei & 97.17 & 97.23 & 94.42 \\
\hline Juni & 97.47 & 97.33 & 95.96 \\
\hline Juli & 97.07 & 96.76 & 93.62 \\
\hline Agustus & 95.76 & 94.87 & 95.01 \\
\hline September & 95.87 & 95.14 & 97.93 \\
\hline Oktober & 94.91 & 96.39 & 97.93 \\
\hline November & 96.80 & 96.10 & 96.60 \\
\hline Desember & 93.44 & 95.92 & \\
\hline Average & $\mathbf{9 5 . 4 9}$ & $\mathbf{9 6 . 0 0}$ & $\mathbf{9 5 . 7 4}$ \\
\hline
\end{tabular}

Source : Database of Personnel (SIPEGI) Ministry of Industry

Based on the table above, there was an increase in the value of discipline between 2017 and 2018 by $0.71 \%$, and the performance value also increased between 2017 and 2018 by $0.51 \%$. so it can be seen that the value of discipline has a positive effect on performance, but it is not only the value of discipline that affects performance, so researchers try to examine whether compensation, competence, and leadership also have a positive effect on performance.

The author has conducted a pre-survey with the technique of distributing questionnaires to 30 employees in the ministry of industry as preliminary observations of the study. The results of the study can be seen in Picture 1, below.

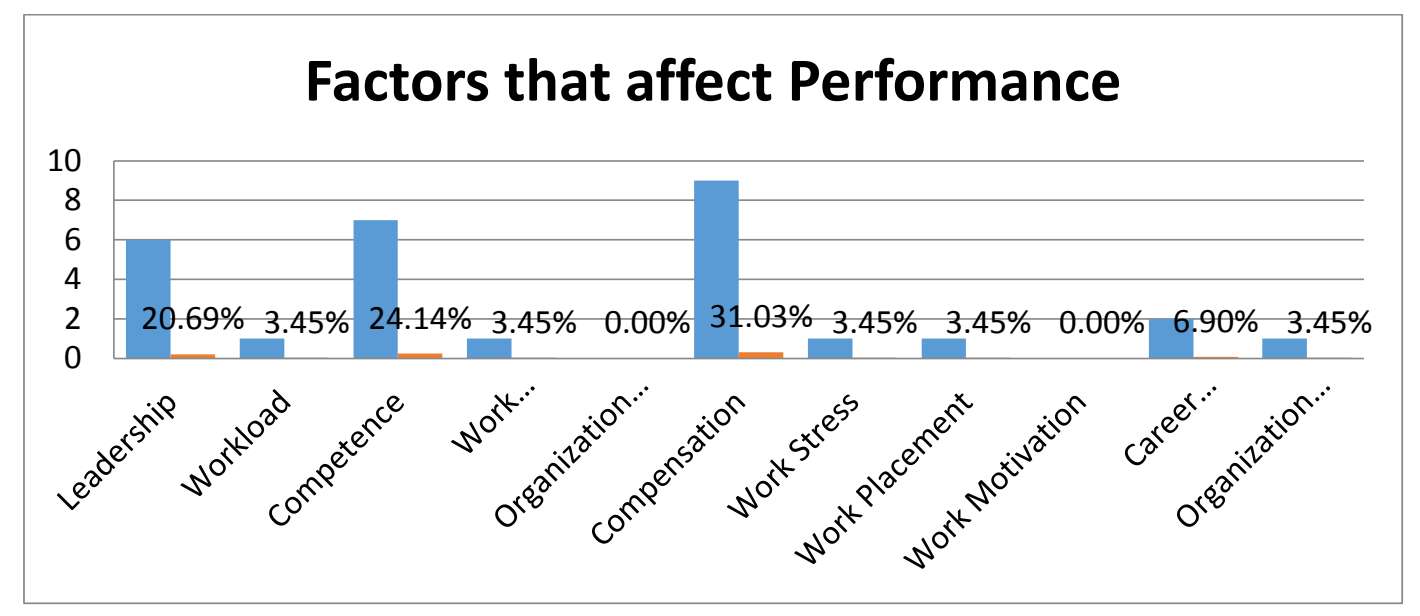

Picture 1. Factors affecting performance at the ministry of industry

Source : Pre-Survey at the ministry of industry (2019)

Based on the picture above there are several dominant factors, including: Compensation as much as $31.03 \%$ (9\%), Competence as much as $24.14 \%$ and Leadership as much as $20.69 \%$. Based on the background description and pre-survey results above, the researcher takes the title. "THE EFFECT OF COMPENSATION, COMPETENCE, DREAMS OF PERFORMANCE IN THE MINISTRY OF INDUSTRY".

\section{LITERATURE REVIEW}

\section{Compensation}

According to Dessler (2009: 46) Employee Compensation refers to all forms of payment or gifts for employees and comes from their work. Employee Compensation has two main components of direct payments (in the form of wages, salaries, 
incentives, commissions and bonuses) and indirect payments (in the form of financial benefits such as insurance and holidays paid by employers, etc.). According to Mondy (2008: 3), compensation is the total reward received by employees as a substitute for the services they have provided, Rivai (2011: 74) states that compensation is something that employees receive in exchange for their service contribution to the company

\section{Competence}

According to Palan (2007: 6) said that "Competence (competence), competency models and competency-based training is a word that can be interpreted differently following its definition. Spencer and Spencer in Palan (2007: 84) suggest that competence shows the characteristics that underlie behavior that describe motives, personal characteristics (characteristics), self-concept, values, knowledge or expertise brought by someone who performs superior (superior performers) in workplace.

\section{Leadership}

According to Yukl (2009: 26), leadership is the process of influencing others to be able to understand and agree on what needs to be done as well as how to do it, including the process of facilitating the efforts of individuals or groups in meeting common goals. Meanwhile, according to (Pramudyo, 2010), leadership is a leadership behavior that is shown by leaders in leading and directing their employees. Peter G. Northouse (2010: 3) leadership is a process in which an individual influences a group of individuals in order to achieve common goals.

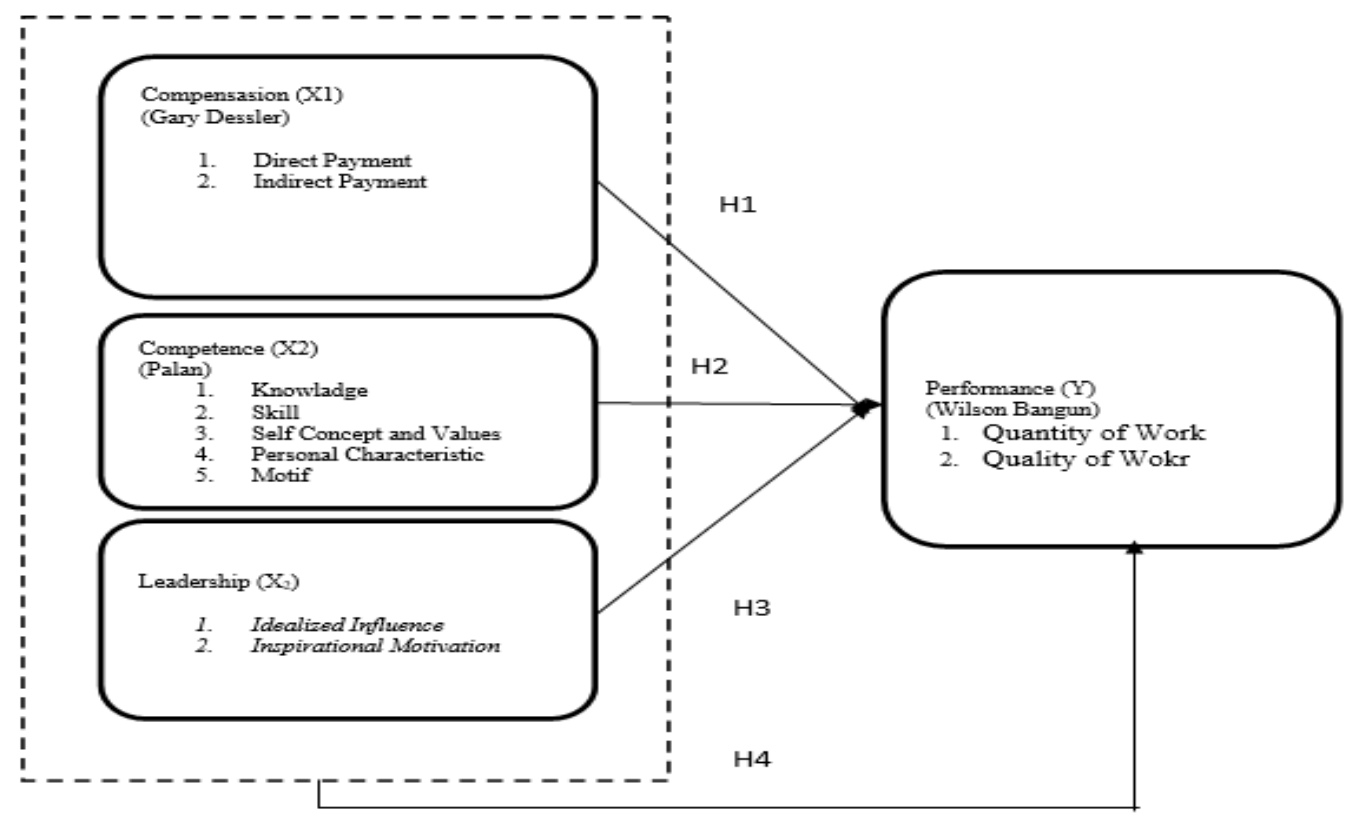

Picture 2. Conceptual Framework

H1 : Compensation affects employee performance

$\mathrm{H} 2$ : Competence affects employee performance

H3 : Leadership influences employee performance

H4 : Compensation, Competence and Leadership jointly affect employee performance. 


\section{RESEARCH METHODS}

\section{Type of Research}

Research design is a framework used to carry out research. Based on the background of the problem, the objectives and the proposed hypothesis, this study belongs to quantitative research with axioms or the basic view of the relationship between the variables is causal or causal. The purpose of causal research is to obtain evidence of how much influence the independent variable has on the dependent variable (Sugiono, 2014: 11).

\section{Research Sites}

This research was conducted at the Ministry of Industry with respondents of Civil Servants at the Directorate General of International Industrial Cooperation located at Jl. General Gator Subroto Kav. 52-53 South Jakarta.

3. Population and Sample

The adjusted population is 101, with the limitation of the sample with an inaccuracy rate of 5\%, then using the Slovin formula above obtained a sample of :

$$
\begin{aligned}
& n=\frac{101}{1+101(0.05)^{2}} \\
= & 81 \text { Responden }
\end{aligned}
$$

The results of the above calculation, the authors decided to take a sample of 81 staff.

4. Variable Measurement Scale

In this study the authors set a measurement scale that is Likert scale with ordinal type, in which the authors determine their own value range of answers. The Likert scale used is adjusted to the type of question used on the variable, with a range of scores from 1 to 5 . The definition of the Likert scale score used can be seen in Table 2 as follows:

Table 2. Likert Scale

\begin{tabular}{ccc}
\hline Score & \multicolumn{2}{c}{ Definition of a Likert Scale Score } \\
\hline $\mathbf{5}$ & SS & Strongly Agree \\
$\mathbf{4}$ & S & Agree \\
$\mathbf{3}$ & CS & Quite Agree \\
$\mathbf{2}$ & TS & Not Setuju \\
$\mathbf{1}$ & STS & Strongly Disagree \\
\hline
\end{tabular}

Source : Sugiyono (2014)

\section{Data Collection Techniques}

Primary and secondary data collection techniques

\section{Data Analysis Techniques}

Data analysis techniques in this study used multiple regression analysis (multiple regression analysis) with the help of IBM SPSS (Statistical Product and Service Solutions) version 24.

\section{FINDINGS AND DISCUSSION}

Based on the results of SPSS 24 output on multiple linear regression equations produced in this study are:

$$
\mathrm{Y}=2,585+0,005 \mathrm{X} 1+0,246 \mathrm{X} 2+0,367 \mathrm{X} 3+\mathrm{e}
$$

The Regression Equation can be interpreted as follows:

1) The value of Constants a is equal to 2.585 this shows that if Compensation (X1), Competency (X2) and Leadership (X3) are each worth 0, then Performance (Y) is 
worth 2.585, this Performance Value shows that the level of Performance is Less Agree, so it needs to be controlled using Compensation (X1), Competence (X2) and Leadership (X3).

2) Compensation independent variable (X1), has a coefficient value of 0.005 This means that if the other independent variables are of fixed value and the Compensation variable $(\mathrm{X} 1)$ has increased or increased, the performance will increase by $0.5 \%$.

3) Competency independent variable (X2) has a coefficient value of 0.246. This means that if the other independent variables are fixed and the Compensation variable (X2) has increased or increased, the performance will increase by $24.6 \%$.

The independent variable of Leadership (X3) has a coefficient value of 0.367 . This means that if the other independent variables are of fixed value and the Leadership (X3) variable has increased or increased, then Performance will experience an increase of $36.7 \%$.

\section{Determination Coefficient Test (R2 Test)}

Table 3. Result Determination Coefficient

\begin{tabular}{|c|c|c|c|}
\hline Score $\mathbf{R}$ & Score $\mathbf{R}^{\mathbf{2}}$ & Score Adjuster $\mathbf{R}^{\mathbf{2}}$ & $\begin{array}{c}\text { Std. Error of the } \\
\text { Estimate }\end{array}$ \\
\hline $0,353^{\mathrm{a}}$ & 0,125 & 0,091 & 0,65717 \\
\hline
\end{tabular}

Source : Data Processing Results with SPSS (2019)

This shows that Compensation (X1), Competence (X2) and Leadership (X3) explain Performance (Y) of $12.5 \%$, while $87.5 \%$ is explained by other factors.

Simultan Test (F Test)

Table 4. Result ANOVA Test (Uji-F)

\begin{tabular}{|c|c|c|c|c|c|c|}
\hline \multicolumn{2}{|r|}{ Model } & $\begin{array}{c}\text { Sum of } \\
\text { Squares }\end{array}$ & df & $\begin{array}{l}\text { Mean } \\
\text { Square }\end{array}$ & $\mathrm{F}$ & Sig. \\
\hline \multirow[t]{3}{*}{1} & Regression & 4.746 & 3 & 1.582 & 3.663 & $.016^{\mathrm{b}}$ \\
\hline & Residual & 33.254 & 77 & 0.432 & & \\
\hline & Total & 38.000 & 80 & & & \\
\hline
\end{tabular}

Source : Data Processing Results with SPSS (2019)

Based on the ANOVA test results in the table above, it can be seen that the F-count value of 3.668 with a significance value of 0.016 because the significance value is smaller than the alpha value of 5\%, according to the basis of decision making in the $\mathrm{F}$ test, it can be concluded that the Compensation variable (X1), Competence (X2) and Leadership (X3) simultaneously have a significant effect on performance.

\section{Partial Test ( $t$ test)}

Table 5. Result Hipothesys (t test)

\begin{tabular}{ccccc}
\hline Hipotesis & $\begin{array}{c}\text { Sroce t- } \\
\text { count }\end{array}$ & $\begin{array}{c}\text { Score t } \\
\text { tabel }\end{array}$ & $\begin{array}{c}\text { Score } \\
\text { Signifikansi }\end{array}$ & Results Test \\
\hline H1 : Compensasion $\rightarrow$ & 0,134 & 0.2213 & 0.893 & No Supported \\
$\begin{array}{c}\text { Performance } \\
\text { H2 }: \text { Compentence } \rightarrow \\
\begin{array}{c}\text { Performance } \\
\text { H3 }: \text { Leadership } \rightarrow \\
\text { Performance }\end{array}\end{array}$ & 2,731 & 0.2213 & 0.008 & Supported \\
\hline
\end{tabular}

Source : Data Processing Results with SPSS (2019) 
The results of testing the research hypotheses in table 5 above, are described as follows:

H1. Based on the value of the regression analysis obtained by the t-value of $0.134<0.2213$ and the significance value (sig.) $0.893>0.05$, it can be concluded that Ho is accepted and $\mathrm{H} 1$ is rejected. Thus, this hypothesis proves "Compensation (X1) has no effect and is not significant on Performance (Y)".

$\mathrm{H} 2$ Based on the value of the regression analysis obtained t-value of $2.731>0.2213$ and the significance value (sig.) $0.008<0.05$, it can be concluded that Ho is rejected and $\mathrm{H} 1$ is accepted. Thus, this hypothesis proves "Competence (X2) has significant and significant effect on Performance (Y)".

H3 Based on the value of the regression analysis obtained t-value of 2.192>0.2213 and the significance value (sig.) $0.031<0.05$, it can be concluded that Ho is rejected and H1 is accepted. Thus, this hypothesis proves "Leadership (X3) influential and significant on Performance (Y)".

Table 6. Result Matrix Correlation Between Dimensions

\begin{tabular}{|c|c|c|c|}
\hline \multicolumn{2}{|c|}{ Correlations } & \multicolumn{2}{|c|}{ Performance } \\
\hline $\begin{array}{c}\text { VARIABLE } \\
\text { INDEPENDENT }\end{array}$ & DIMENSION & $\begin{array}{l}\text { Quantity of } \\
\text { Work (Y1) }\end{array}$ & $\begin{array}{l}\text { Quality of } \\
\text { Work (Y2) }\end{array}$ \\
\hline \multirow{2}{*}{$\begin{array}{l}\text { COMPENSASION } \\
\text { (X1) }\end{array}$} & Direct Payment (X1.1) & -0.070 & -0.070 \\
\hline & $\begin{array}{l}\text { Indirect Payment } \\
\text { (X1.2) }\end{array}$ & 0.213 & 0.122 \\
\hline \multirow{5}{*}{ COMPETENCE (X2) } & Knowladge (X2.1) & 0.377 & 0.037 \\
\hline & Skills (X2.2) & -0.089 & -0.110 \\
\hline & $\begin{array}{l}\text { Self - Concept \& } \\
\text { Values }(\mathrm{X} 2.3)\end{array}$ & 0.069 & 0.085 \\
\hline & $\begin{array}{l}\text { Personal Characteristic } \\
(\mathrm{X} 2.4)\end{array}$ & 0.425 & 0.295 \\
\hline & Motif (X2.5) & 0.254 & 0.207 \\
\hline \multirow[t]{2}{*}{ LEADERSHIP (X3) } & $\begin{array}{l}\text { Idealized influence } \\
\text { (X3.1) }\end{array}$ & -0.040 & 0.009 \\
\hline & Inspirational (X3.2) & 0.180 & 0.243 \\
\hline
\end{tabular}

Source : Data Processing Results with SPSS (2019)

\section{CONCLUSION AND SUGGESTION}

The results showed that Compensation (X1) had no effect and was not significant to Performance (Y). Then the results of this study support previous research that compensation has no significant positive effect on performance (Mokhamad Yanuar Pradita, 2017), (Firmandari, 2014).

A strong correlation relationship occurs in the Indirect Dimension (X1.2) with the Work Variable (Y) in the Quantity Result of Work (Y1), this shows that the fullest indirect compensation will improve performance.

According to Kasmir (2016), compensation is in return for services provided by a company to the performance or work performance of its employees. The company will provide compensation to employees involved in it, if the employee has done a good job or has achievements in his work. The high compensation provided by the company will affect 
the increase in workload or work targets received by employees, the company will demand that employees work optimally if they want high compensation. If the employee does not work optimally or goes down, high compensation will not be achieved. As a form of responsibility employees sometimes have to go home at night to achieve the targets set by the company. The level of fatigue in meeting the target, causing compensation is no longer a hope. Based on this condition, it is very natural that compensation does not affect performance.

The results showed that Competence (X2) influences and significantly affects Performance (Y). So the results of this study support previous research that competence has a significant effect on employee performance (Samsul Arifin, et al, 2019).

A strong correlation relationship occurs in the Dimensions of Personal Characteristics (X2.4) with Work Variables (Y) on the Quantity of Work Results (Y1), this shows that the fullest personal characteristics will improve performance.

Companies need competent employees, because employees who have competence will be relatively easier to do the work and can be developed. Because basically they already have good skills to complete the work that has been set effectively so that it can help the company achieve targets and can improve the performance of higher quality employees. Other studies Streuner and Bjoruest (1998) conclude that competence is the ability of individuals to perform tasks that have been assigned to them. Moreover, the concept of competence can also be understood as knowledge, skills, and professional identity. As far as the commitment of the employees concerned.

The results showed that the leadership (X3) influential and significant on performance (Y). So the results of this study support previous research that leadership has a significant effect on employee performance (Samsul Arifin, et al, 2019).

Correlation relationship is strong enough between the Inspirational Dimension (X3.2) with the Performance Variable (Y) on the dimension of Quality of Work Results (Y2), this shows that if the fulfillment of an Inspirational leader then employee performance will increase. A leader must have an authoritative and firm attitude in carrying out his leadership. Leadership position in the company is very important to smooth the achievement of company goals. Because the success of a company is really determined by the quality of leadership. Leaders also become role models for employees because with wise leaders and not arbitrary to employees when leading by not discriminating among employees, this will lead to enthusiasm and motivation of employees to be more active at work. According to Darmawan et al. (2018) employees when working, it is not enough just to be directed but must be supervised by the leadership so that what is done by the employees can run well.

Based on the results of the study it can be concluded that compensation, competence and leadership jointly or simultaneously affect the performance. So it can be concluded that compensation, competence and leadership are variables that greatly affect performance.

\section{REFERENCE}

Dessler Gary, 2009. Manajemen Sumber Daya Manusia, Jakarta :Edisi Kesepuluh Jilid Dua PT Indeks halaman 46.

Mondy, Wayne. (2008). Manajemen Sumber Daya Manusia Jilid 1. Jakarta: Erlangga.

Rivai, Veithzal. 2011, Manajemen Sumber Daya Manusia untuk Perusahaan: dari Teori ke Praktik, Jakarta : RajaGrafindo Persada 
Palan (2007) Competency Management : Teknis Mengimplementasikan Manajemen Sumber Daya Manusia Berbasis Kompetensi untuk meningkatkan Daya Saing Organisasi. PPM. Salemba Empat, Jakarta.

Yulk, Gary (2010). Kepemimpinan dalam Organisasi, Edisi Kelima, Jakarta, PT Indeks 